(C) Лавренко А.В., Борзих О.А.

УДК: 616.441-008.64-06:616.1

DOI https://doi.org/10.31718/mep.2021.25.5-6.08

\title{
ДЕКОМПЕНСОВАНИЙ ВИПАДОК ГІПОТИРЕОЗА 3 УРАЖЕННЯМ СЕРЦЕВО-СУДИННОЇ СИСТЕМИ
}

\author{
Лавренко А.В., Борзих О.А.
}

Полтавський державний медичний університет

We present a clinical case that demonstrates a lack of compliance in a patient with hypothyroidism, which led to severe complications of the cardiovascular system. The clinical feature of this case is the development of severe complications of hypothyroidism due to the patient's low adherence to therapy and untimely treatment. The patient had all characteristic signs of severe hypothyroidism with heart and skin lesions (total alopecia, edema, dryness and peeling of the skin). Fully available diagnostic criteria were as follows: critical disorders of thyroid hormone levels in the blood, hyperenzymemia, hypothyroidism, fluid in the pleural cavity, increased heart shadow, fluid in the pericardial cavity, left ventricular dilatation, decreased ejection fraction, arrhythmia. The predominant lesion of the cardiovascular system is characteristic of such cases and prevailed in the clinical presentation of the disease and was the direct reason for seeking medical help. Under the influence of treatment, the patient's sinus rhythm was restored, myocardial contractility improved, there was no fluid in the pericardial cavity and pleural cavity, edema decreased, mental activity and emotional state improved. However, the patient flatly refused further observation and treatment. As a result, hypothyroidism is underdiagnosed. Initiation of treatment in the early stages of the disease and prevention of complications relies on early diagnosis through systematic screening according to the recommendations. Heart disease, associated with hypothyroidism is a condition that can be prevented if it is detected and treated by family doctors in a timely manner in an outpatient setting. Timely detection of the disease and hospitalization will allow avoiding serious complications of hypothyroidism, timely diagnosing this pathology and prescribing adequate therapy according to the stage of the disease.

Key words: hypothyroidism, diagnosis, severe cardiovascular complications.

Нами представлений клінічний випадок, який демонструє відсутність комплаєнсу пацієнтки з гіпотиреозом, що призвело до важких ускладнень з боку серцево-судинної системи. Клінічною особливістю даного випадку є розвиток важких ускладнень гіпотиреозу внаслідок низької прихильності хворої до лікування з несвоєчасним зверненням до лікаря. У хворої спостерігались всі характерні ознаки важкого перебігу гіпотиреозу з ураженням серця та шкіри (тотальна алопеція, набряки, сухість та лущення шкіри). Повною мірою наявні діагностичні критерії - критичні розлади рівнів тиреоїдиних гормонів в крові, гіперферменемія, гіпоплізія щитоподібної залози, рідина у плевральній порожнині, збільшення тіні серця, рідина у порожнині перикарду, розширення лівого шлуночка, зменшення фракції викиду, порушення ритму, провідності серця, низький вольтаж зубців на ЕКГ. Ураження серцевосудинної системи характерне для таких випадків та переважало в клінічній картині хвороби і стало безпосередньою причиною звернення за медичною допомогою. Під впливом лікування у хворої відновився синусовий ритм, покращилася скоротлива здатність міокарда, відсутня рідина в порожнині перикарду та плевральній порожнині, зменшилися набряки, покращилася розумова активність та емоційний стан. Однак хвора категорично відмовилась від подальшого спостереження та лікування. У підсумку, спричинені гіпотиреозом захворювання серця недостатньо діагностовані. Початок лікування на ранніх стадіях захворювання та запобігання ускладнень покладається на ранню діагностику за допомогою систематичного скринінгу згідно з рекомендаціями. Своєчасне виявлення захворювання та звернення пацієнта до лікарні дасть можливість уникнути серйозних ускладнень гіпотиреозу, вчасно діагностувати дану патологію та призначити адекватну терапію відповідно до стадії перебігу захворювання.

Ключові слова: гіпотиреоз, діагностика, важкий перебіг, ускладнення.

Гіпотиреоз - клінічний синдром, спричинений тривалим і стійким дефріцитом гормонів щитоподібної залози в організмі або зниженням їх біологічного ефеекту на тканинному рівні. Поширеність гіпотиреозу серед населення постійно збільшується. В Україні у дорослих частота його серед жінок становить від 1,4 до $2 \%$, а серед чоловіків - 0,2\%. Гіпотиреоз може протікати без виражених клінічних ознак, через це багато випадків захворювання залишаються вчасно не діагностованими.

Слід зазначити, що дисфункція щитовидної залози $\epsilon$ поширеною випадковою знахідкою навіть серед здорових людей, тож пацієнти не завжди можуть оцінити складність ситуації, що є причиною несвоєчасного звернення пацієнта до лікаря та знижує комплайс відвідувань лікаря.

Медико-соціальне значення гіпотиреозу визнача- ється не лише його поширеністю і тенденцією до подальшого збільшення кількості хворих, але і тими збитками, що наносить гіпотиреоз пацієнту як хронічне захворювання. Перш за все це стосується патології серцево-судинної та нервової систем $[4,6]$.

Розвиток гіпотиреозу має глибокий вплив на серцеву функцію, що може впливати на скоротливість серця, опір судин, кров'яний тиск і серцевий ритм [3].

Серед багатьох інших серцевих ускладнень, захворювання може призвести до перикардіального випоту. Тож за даними науковців гіпотиреоз викликає перикардіальний випіт через підвищення проникності епікардіальних судин і зниження лімфатичного дренажу альбуміну, що призводить до накопичення рідини в перикардіальному просторі, (з частотою 3\%-37\%) і може викликати тампонаду серця у важких випадках $[1,2]$.

*Цитування при атестації кадрів: Лавренко А.В., Борзих О.А. Декомпенсований випадок гіпотиреоза з ураженням серцевосудинної системи // Проблеми екології і медицини. - 2021. - Т. 25, № 5-6. - С. 32-35. 


\section{Клінічний випадок}

Представлений клінічний випадок низького комплаєнсу та несвоєчасного звернення пацієнтки з гіпотиреозом та виникненням важких ускладнень з боку серцево-судинної системи.

Хвора К., - жінка, 62 років, пенсіонерка, доставлена 23.08.2019 року в приймальне відділення міської лікарні зі скаргами на виражену задишку, утруднене дихання, відчуття втрати свідомості, запаморочення, загальну слабкість.

Із анамнезу відомо, що пацієнтка вважає себе хворою близько 10 років, відзначала слабкість, втомлюваність, набряки тулуба, гомілок, серцебиття, задишку, важкість в ділянці серця, періодично приймала самостійно торасемід, панангін, лікувалася самостійно по рекомендації знайомих, до лікаря не зверталась.

Стан хворої поступово погіршувався, наростала задишка, набряки, сухість шкіри, втрата волосся на шкірі голови, осиплість голосу. Зранку 23.08.2019 стан хворої різко погіршився, симптоми посилилися, хвора викликала бригаду екстреної медичної допомоги. Лікар при огляді відзначив важкий стан хворої, ЧДР - 30 за хвилину, дихання самостійне. $\mathrm{SpO}_{2}-76 \%$. Пульс 100 за 1 хв., АТ - 120/80 мм.рт.ст. Проведена ЕКГ, визначення глюкози крові - 6,9 ммоль/л. Хворій надана екстрена допомога: киснева терапія (маска), еноксапарін 0,8 підшкірно, розпочата інфузійна, симптоматична терапія, екстрена госпіталізація. Пацієнтка була доставлена бригадою в приймальне відділення міської лікарні з діагнозом: Гостра дихальна недостатність. ТЕЛА (23.08.19)? Двопучкова блокада правої та передньої гілки лівої ніжки пучка Гіса (23.08.19). Стан після втрати свідомості (23.08.19). Синдром Шегрена?

Під час огляду та обстеження хворої в клініці додатково із анамнезу життя з'ясовано, що хвора зростала та розвивалась в нормальних побутових умовах. Інфекційні захворювання та цукровий діабет заперечує. Травм, операцій не було. Алергологічний анамнез не обтяжений. До лікаря останні 10 років не зверталась. Зі слів хворої хронічної патології не мала. Загальний стан хворої розцінений як тяжкий. Хвора в свідомості, загальмована, важко доступна продуктивному контакту. Обличчя одутле. Тотальна алопеція. Шкірні покриви чисті, бліді, на дотик сухі. Відзначається значне лущення шкіри тіла, найбільше виражене на кінцівках (рис. 1А,Б)

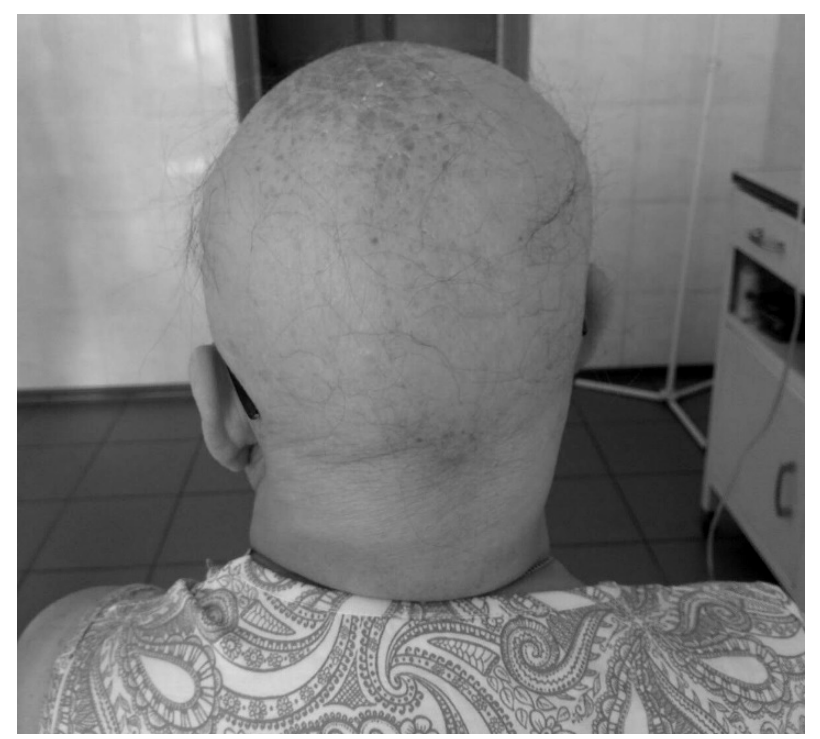

Рис. 1-A. Тотальна алопеція у хворої на гіпотиреоз.

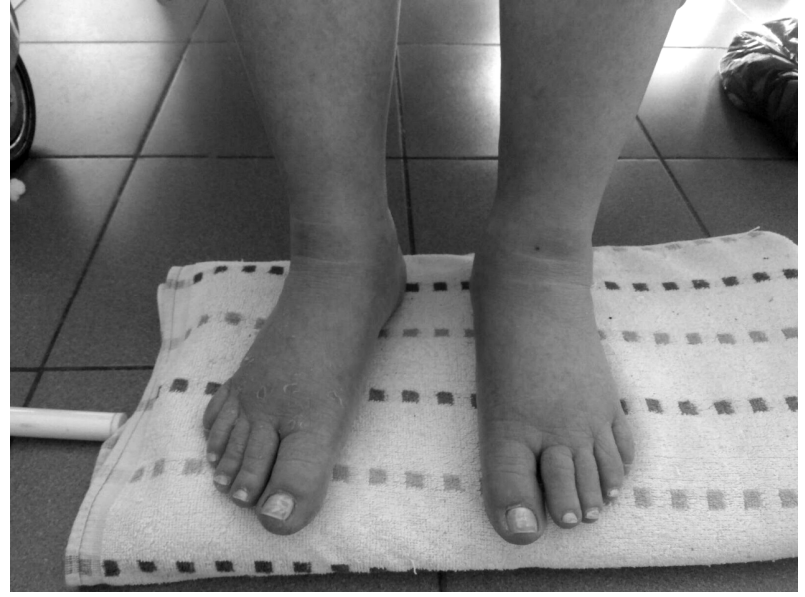

Рис. 1-Б. Набряки та виражене лущення шкіри у хворої на гіпотиреоз.

Периферичні лімфовузли не збільшені. Набряки обличчя, тулуба, кінцівок. ЧДР - 28 за хвилину, дихання самостійне. $\mathrm{SpO}_{2}-82 \%$. Температура тіла $-36,0^{0}$ С. При перкусії легень спостерігається притуплення легеневого звуку в нижніх відділах з обох боків. При аускультації дихання жорстке, в нижніх відділах ослаблене. Пульс 86 за 1 хв., АТ - 120/80 мм.рт.ст. Межі відносної тупості серця розширені вліво на 3,0 см, вправо на 2,0 см. Тони серця аритмічні, ослаблені, акцент II тону на аорті. Язик збільшений, з відбитками зубів, обкладений білим нальотом. Живіт м'який, безболісний, доступний глибокій пальпації. Перистальтика вислуховується в усіх відділах. Печінка збільшена, виступає на 4 см з під краю реберної дуги. Симптом постукування негативний з обох боків.

Проведено обстеження: Загальний аналіз крові (23.08.2019) гемоглобін -110 г/л, еритроцити - 3,6 x $10^{12}$; кольоровий показник - 0,91, лейкоцити - 5,0 х $10^{9}$; швидкість зсідання еритроцитів - 15 мм/год; лейкоцитарна формула: паличкоядерні - $2 \%$; сегментоядерні - 67\%; еозинофріли - 1\%; лімфоцити - 25\%; моноцити - 5\%; базофріли - 0\%. Біохімічний аналіз крові (23.08.2019): білірубін - 16,6-4,15-12,2 мкмоль/л; загальний білок - 81 г/л, альбумін - 44 г/л, сечовина - 5,5 ммоль/л, креатинін - 95 ммоль/л; глюкоза крові - 5,4 ммоль/л; АСТ - 46 Од/л (менше 35), АЛТ-15 Од/л, лДГ - 979 Од/л ( 114-450 Од/л), КФК - 2064 Од/л (менше 170), холестерин - 7,53 (3,6-6,5 ммоль/л), СРБ - негативний, АСЛ-О - нижче 250, РФ - негативний. еШКФ (CKD-EPI) - 55,98 мл/Хв. Тиреоїдна панель: АТ до ТПО - 247,8 IU/ml $(\mathrm{N}<63)$, ТТГ - $235 \mu \mathrm{lU} / \mathrm{ml}(0,27-4,4)$, $\mathrm{T}_{4}-3,5 \mathrm{pmol} / \mathrm{l}(12,0-22,0), \mathrm{T}_{3^{-}} \leq 0.400 \mathrm{pmol} / \mathrm{l}(3,95-$ $6,80)$. Коагулограма: протромбін $74 \%$, фібриноген 3,5 г/л. Загальний аналіз сечі (25.08.2019): сеча - світло-жовта, реакція-кисла, питома вага - 1019, жовчні пігменти - негативні, білок - 0,183 г/л, лейкоцити 12-14 в п/3, еритроцити на $1 / 4 \pi / 3$.

УзД щитовидної залози (23.08.2019): права доля $-1,5 \times 1,4 \times 3,0=3 \mathrm{~cm}^{3}$, ліва доля $-1,3 \times 1,3 \times 1,8=$ $1,5 \mathrm{~cm}^{3}$, перешийок - 0,3 cм, тканина залози пониженої ехогенності, неоднорідна. Висновок: УЗД-ознаки гіпоплазії щитоподібної залози. Ультразвукове дослідження органів черевної порожнини (23.08.2019). Висновок: УЗД-ознаки жирового гепатозу, хронічного холециститу, панкреатиту, стончення паренхіми нирок, гідрокалікозу, ущільнення чашково-мискової системи, сечового діатезу, помірний гідроторакс зліва (смужка рідини до 1,5 см). Ехокардіоскопічне дослі- 
дження (ЕхоКС) (23.08.2019): Наявні ознаки зниження скоротливої здатності міокарда (ФВ - 41\%), фріброз стулок аортального та мітрального клапанів, відносна недостатність мітрального клапану. Збільшення лівого шлуночку. Наявність рідини в перикарді (випіт до 0,5 в передній камері та 0,8 см в задній камері перикарду під час діастоли). Електрокардіографія (ЕКГ)

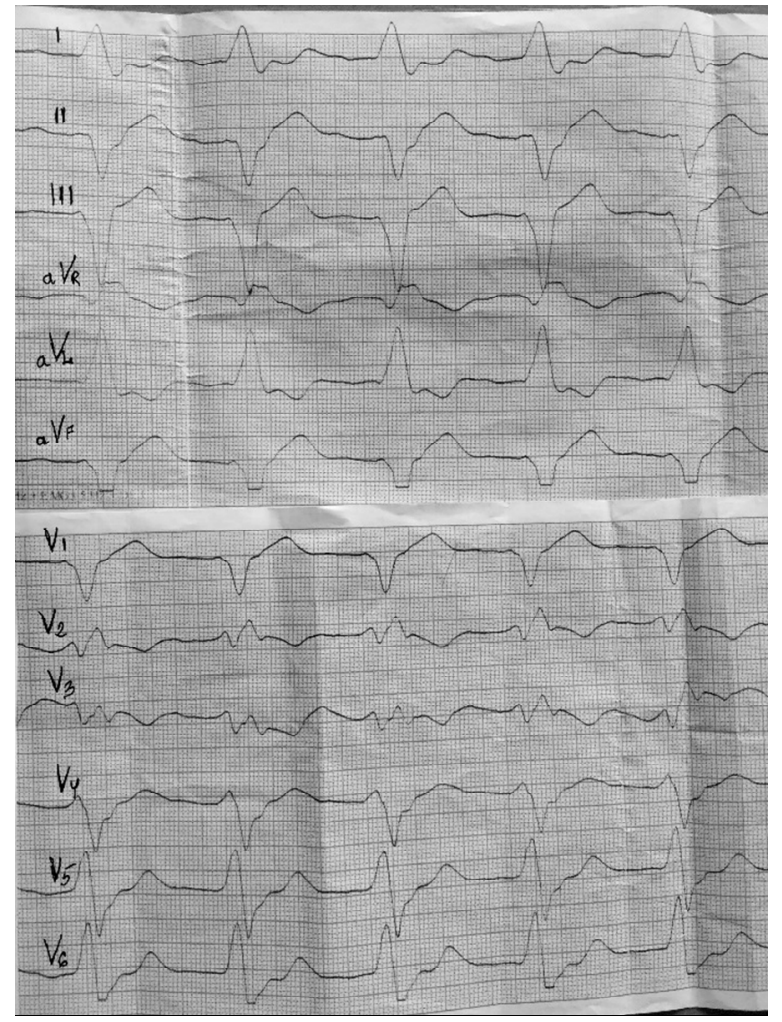

Pис. 2-А. ЕКГ хворої на гіпотиреоз до лікування (23.08.19) ЧСС - 90 за 1 хвилину. Тріпотіння передсердь, регулярна форма 2:1. Двопучкова блокада правої та передньої гілки лівої ніжки пучка Гіса. Субендокардіальна ішемія бокової стінки лівого шлуночка.

Ренгенографія органів грудної клітки (ОГК) (23.08.2019): Пневмофіброз, посилення, згущення легеневого малюнку, серце значно розширено в поперечнику.

\section{Проведені консультації спеціалістів.}

Консультація кардіолога (23.08.2019). Діагноз: Міокардіодистрофрія з дилятацією ЛШ. Тріпотіння передсердь 2:1. Двухпучкова блокада. СН ІІБ, ФК ІІІ зі зниженою систолічною функцією ЛШ ( ФВ 41\%). Хронічна хвороба нирок (XXH)? Артеріальна гіпотензія. Анемія. Консультація ендокринолога (23.08.2019). Діагноз: Гіпотиреоз, тяжка форма в ст. декомпенсації.

На підставі проведеного обстеження встановлений клінічний діагноз:

Гіпотиреоз, тяжка форма в ст. декомпенсації. Міокардіодистрофія з дилятацією ЛШ. Тріпотіння передсердь 2:1. Двухпучкова блокада. СН ІІБ, ФК III зі зниженою систолічною функцією ЛШ ( ФВ 41\%). Гідроторакс, гідроперикард XXН ЗА. Пієлонефрит, прихований перебіг, загострення. Сольовий діатез. Артеріальна гіпотонзія. Анемія.

Розпочато лікування: еутирокс (L-тироксин) 75 мг/добу; гідрокортизон 50 мг/добу; еноксипарін 0,4 мл/добу; цефтріаксон 2,0 г/доба довенно, сіднофрарм 6 мг/добу; аторвостатин 40 мг/добу; мельдоній 5,0 довенно щодня; торасемід 10 мг/добу; спіроналактон 100 мг/добу; інфузійна терапія (розчини хлористого
(23.08.19) ЧСС - 90 уд/хв, тріпотіння передсердь, регулярна форма 2:1, ЕВС відхилена вліво, двопучкова блокада правої та передньої гілки лівої ніжки пучка Гіса, ознаки гіпертрофрії обох шлуночків, систолічне навантаження на правий шлуночок, субендокардіальна ішемія бокової стінки лівого шлуночка (рис. 2А).

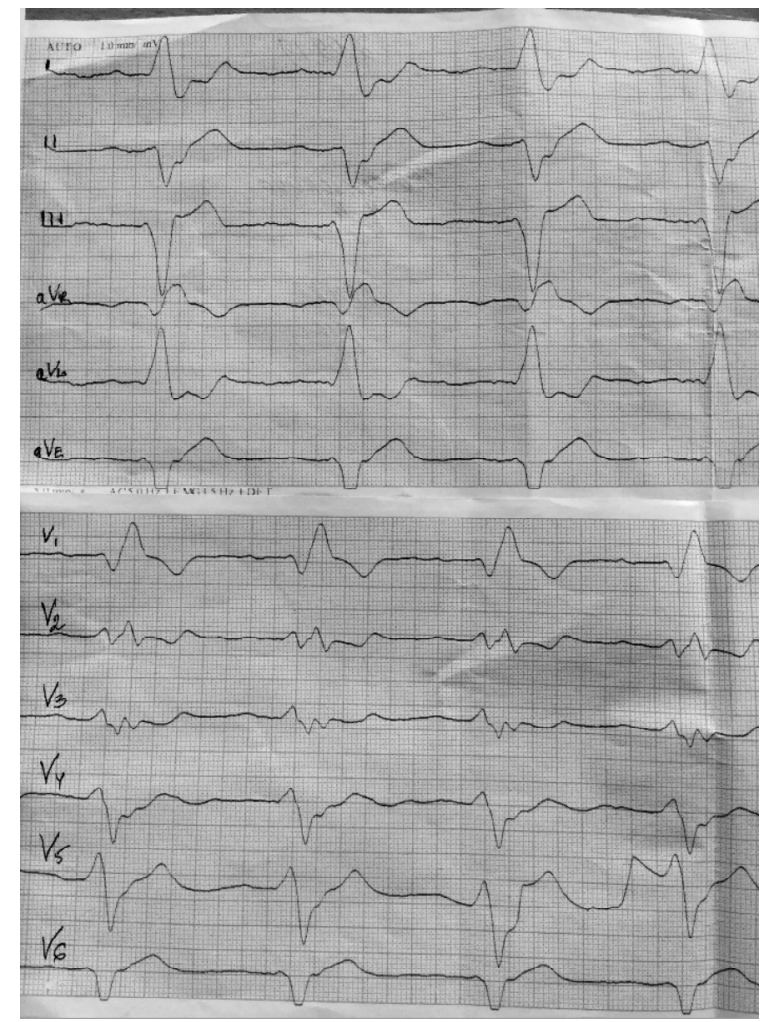

Pис. 2-Б. ЕКГ хворої на гіпотиреоз після лікування (02.09.19). Ритм синусовий, ЧСС - 65 за хвилину, двопучкова блокада правої та передньої гілки лівої ніжки пучка Гіса, систолічне навантаження на правий шлуночок.

натрію 0,9\%, хлористого калію 4\%, глюкози 5\%, Рінгера), симптоматична терапія.

Під час знаходження в клініці хвора продовжувала лікування та обстеження для уточнення діагнозу, знаходилася під наглядом спеціалістів відділення інтенсивної терапії, терапевтичного відділення, співробітниками Клініки внутрішньої медицини, кафедри. Проводилась корекція лікування, доз призначених препаратів. Була поступово збільшена доза еутироксу, з 28.08.19 препарат призначений в дозі 150 мг/добу. Впродовж тижня відзначена позитивна динаміка клініко-лабораторних показників, однак стан хворої залишався важким, зберігалися ознаки ураження ендокринної та серцево-судинної систем, шкіри.

Проведено додаткове обстеження. ЕКГ (02.09.19): Ритм синусовий, ЧСС 65 уд/хв, ЕВС відхилена вліво, двопучкова блокада правої та передньої гілки лівої ніжки пучка Гіса, систолічне навантаження на правий шлуночок (рис.2Б).

Консультація ендокринолога (27.08.2019) - Гіпотиреоз, тяжка форма в ст. декомпенсації. Аутоімунний тиреоїдит. Електроліти крові (28.08.2019): К-3,6 ммоль/л, $\mathrm{Na}$ - 156,4 ммоль/л, Сl - 99 ммоль/л. Тиреоїдна панель (30.09.21): АТ до ТПО - $248 \mathrm{IU} / \mathrm{ml}(\mathrm{N}<63)$, TTГ - 213,3 $\mu \mathrm{lU} / \mathrm{ml} \quad(0,27-4,4), \mathrm{T}_{4}-5,5 \mathrm{pmol} / \mathrm{l}$ $(12,0-22,0), T_{3}-1.26 \mathrm{pmol} / \mathrm{l}(3,95-6,80)$. Загальний аналіз крові (02.09.2019) - без суттевої динаміки. 
Загальний аналіз сечі (01.09.2019) сеча світложовта, реакція -кисла, питома вага-1012, жовчні пігменти - негативні, білок - сліди, епітелій- рідко, лейкоцити - 4-6 в п/3, еритроцити - 1-3 в п/3, циліндринемає. ЕхоКГ (02.09.19): Ознаки зниження скоротливої здатності міокарда (ФВ 46\%), помірний фріброз стулок мітрального клапану. Збільшення лівого шлуночка. Ренгенографрія ОГК (02.09.2019): Прозорість нижніх відділів і правого синуса відновлена, легеневий малюнок більш структурований, зберігається кардіомегалія і кальциноз дуги аорти.

Під впливом лікування у хворої відновився синусовий ритм, покращилася скоротлива здатність міокарда, відсутня рідина в порожнині перикарду та плевральній порожнині, зменшилися набряки, покращилася розумова активність та емоційний стан. Хвора категорично відмовилась від подальшого спостереження та лікування, 03.09.2019 була виписана з лікарні. Для подальшого лікування рекомендовано: еутирокс (L-тироксин) 200 мг/добу; сіднофрарм 6 мг/добу; аторвостатин 30 мг/добу; мельдоній 500 мг щодня; торасемід 10 мг/добу; спіроналактон 100 мг/добу. Нагляд ендокринолога за місцем проживання.

Заключний діагноз: Первинний гіпотиреоз, тяжка форма в стадії глибокої декомпансації. Аутоімунний тиреоїдит, мікседемна прекома (23.08.19). Ендокринно-обмінна міокардіодистрофрія 3 дилятацією порожнин серця. Порушення ритму по типу фрібриляції передсердь, тріпотіння передсердь, синусовий ритм (27.08.19) CHA2DS2-VASc - 26, HAS-BLED - 1б. CH ІІБ, зниження систолічної функції ЛШ (ФВ 46\% ЕхоКС 02.09.19) ФК III. XXН ЗА. Пієлонефрит, прихований перебіг, загострення. Сольовий діатез. Гідроторакс, гідроперикард. Хронічна анемія середнього ступеня тяжкості.

\section{Результати та їх обговорення}

Клінічною особливістю даного випадку є розвиток важких ускладнень гіпотиреозу внаслідок низької прихильності хворої до лікування з несвоєчасним зверненням до лікаря. У хворої спостерігались всі характерні ознаки важкого перебігу гіпотиреозу з ураженням серця та шкіри (тотальна алопеція, набряки, сухість та лущення шкіри). Повною мірою наявні діагностичні критерії - критичні розлади рівнів тиреоїдиних гормонів в крові, гіперферменемія, гіпоплізія щитоподібної залози, рідина у плевральній порожнині, збільшення тіні серця, рідина у порожнині перикарду, розширення лівого шлуночка, зменшення фракції викиду, порушення ритму, провідності серця, низький вольтаж зубців на ЕКГ.

Переважне ураження серцево-судинної системи характерне для таких випадків та переважало в клінічній картині хвороби і стало безпосередньою причиною звернення за медичною допомогою.

За даними літератури, для лікування уражень серця, що пов'язаної з гіпотиреозом, лікування основного захворювання було успішним у більшості пацієнтів.
Більшість науковців, як і ми, вважають, що ураження серця, що пов'язані з гіпотиреозом, $є$ умовою, яку можна запобігти, якщо її виявляють та лікують сімейні лікарі вчасно в амбулаторних умовах.

Це дозволяє запобігти виникненню різних ускладнень, що виникають при гіпотиреозі, в тому числі перикардіального випоту та аритмій. Такий підхід призведе до кращої якості життя пацієнтів із додатковою перевагою зменшення навантаження на охорону здоров'я через зменшення частоти госпіталізації пацієнтів із важким перебігом хвороби, що підтверджують інші фрахівці [2].

Однак слід з обережністю призначати замісну гормональну терапію та ретельно контролювати загальний стан пацієнтів. При появі побічних явищ (тахікардія, аритмія, підвищена психічна збудливість, тремор кінцівок) слід повернутись до вихідної дози препарату [5].

У підсумку, спричинені гіпотиреозом захворювання серця недостатньо діагностовані. Початок лікування на ранніх стадіях захворювання та запобігання ускладнень покладається на ранню діагностику за допомогою систематичного скринінгу згідно з рекомендаціями $[1,5]$.

Своєчасне виявлення захворювання та звернення пацієнта до лікарні дасть можливість уникнути серйозних ускладнень гіпотиреозу, вчасно діагностувати дану патологію та призначити адекватну терапію відповідно до стадії перебігу захворювання.

\section{Література}

1. Chahine J, Ala CK, Gentry JL, Pantalone KM, Klein AL. Pericardial diseases in patients with hypothyroidism. Heart. 2019 Jul;105(13):1027-33. doi: 10.1136/heartjnl2018-314528.

1. Kaur H, Chakwop Ngassa H, Elmenawi KA, Anil V, Gosal $\mathrm{H}$, Mohammed L. Hypothyroidism-Related Cardiac Tamponade. Cureus. 2021 Oct 8;13(10):e18611. doi: 10.7759 /cureus. 18611.

2. Udovcic M, Pena RH, Patham B, Tabatabai L, Kansara A. Hypothyroidism and the Heart. Methodist Debakey Cardiovasc J. 2017 Apr-Jun;13(2):55-9. doi: 10.14797/mdcj-13-2-55.

3. Khyts AR. Hipotyreoz: medykamentozni uskladnennia [Hypothyroidism: drug complications]. Ukr Med chasopys [Internet]. 13 Lystop 2019. Available from: https://www.umj.com.ua/article/165276/gipotireozmedikamentozni-uskladnennya

4. Melville NA. Hypothyroidism Overtreatment Linked to Risk of Atrial Fibrillation [Internet]. Medscape. 2019 Nov 6. Available https://www.medscape.com/viewarticle/920889

5. Bobyrova Lle, Horodynska Olu. Funktsionalno-adaptyvnyi stan sertsevo-sudynnoi systemy pry hipotyreozi, ishemichnii khvorobi sertsia ta $v$ umovakh komorbidnosti [Functional-adaptive state of the cardiovascular system in hypothyroidism, coronary heart disease and comorbid conditions]. Aktualni problemy suchasnoi medytsyny. 2016;:Tom 18, Vyp. 2(62):16-20.

Матеріал надійшов до редакції 09.11.2021. 